\title{
BENCHMARKING THE KNOWLEDGE MANAGEMENT PRACTICES OF CONSTRUCTION FIRMS
}

\author{
Serdar Kale ${ }^{1}$, A. Erkan Karaman ${ }^{2}$ \\ ${ }^{1}$ Izmir Institute of Technology, Department of Architecture, Urla 35430, Izmir, Turkey \\ ${ }^{2}$ Balikesir University, Department of Civil Engineering, Cagis 10145, Balikesir, Turkey \\ E-mails: ${ }^{1}$ serdarkale@iyte.edu.tr (corresponding author); ${ }^{2}$ ekaraman@balikesir.edu.tr \\ Received 22 Mar. 2010; accepted 10 Mar. 2011
}

\begin{abstract}
Knowledge management is rapidly becoming a key organizational capability for creating competitive advantage in the construction industry. The emergence of knowledge management in this capacity poses enormous challenges to executives of construction firms. This paper proposes a model for benchmarking those knowledge management practices of AEC firms that can guide and assist construction business executives in meeting these challenges. The proposed model incorporates benchmarking and knowledge management concepts with importance-performance analysis (IPA) maps. It is a simple visual tool that can provide powerful diagnostic information to executives of AEC firms by evaluating their firm's knowledge management practices, identifying their firm's comparative advantages and disadvantages with regard to each knowledge management practice, and setting priorities for managerial actions related to knowledge management practices that need improvement. A real-world case study is presented to illustrate the implementation and utility of the proposed model.
\end{abstract}

Keywords: construction management, knowledge management, performance evaluation, benchmarking, construction firms, importance-performance analysis.

\section{Introduction}

There is increasing recognition that knowledge management is a key organizational capability for creating and sustaining competitive advantage in today's construction business environment (e.g., Kululanga, McCaffer 2001; Egbu 2004; Carrillo, Chinowsky 2006; Pathirage et al. 2007). This means that improving and enhancing this key organizational capability should be given high priority by business executives (Wen 2009) and construction management researchers. The process of improving this organizational capability begins with the understanding and evaluation of firm knowledge management practices. Performance measurement models provide construction business executives with meaningful tools and techniques for understanding and evaluating their knowledge management practices. These tools and techniques allow construction business executives to understand and evaluate and in turn improve their knowledge management practices.

Some construction management researchers (e.g., Kululanga, McCaffer 2001; Egbu 2004) have been involved in developing performance measurement models for evaluating knowledge management practices at Architectural Engineering and Construction (AEC) firms. Despite the fact that these models represent an important milestone in the measurement and evaluation of knowledge management practices at AEC firms, the utility of such models is severely limited due to the exclusion of the competitive environments (Chen et al. 2009) in which AEC firms operate. This limitation of previously presented models for evaluating the knowledge management practices of construction firms (e.g., Kululanga, 2001; Egbu 2004) can be overcome using a benchmarking approach. Benchmarking is one of the most powerful performance modeling approaches that enables firms to include competitive dynamics in the evaluation process. It has been a popular performance modeling approach in the construction management literature. Benchmarking has been used for evaluating the success of selected design and build projects (Lam et al. 2004), improving total quality management initiatives at AEC firms (Sommerville, Robertson 2000), assessing construction safety management programs (Fang et al. 2004), and improving project management performance (Luu et al. 2008). However, the prospect of evaluating the knowledge management practices of AEC firms using a benchmarking approach remains relatively unexplored.

The paper presented herein focuses on this relatively unexplored research area. It presents a simple framework for evaluating the knowledge management performance of AEC firms. The proposed framework is a synthesis of benchmarking (Camp 1989), knowledge management models (Gold et al. 2001; Lee, Choi 2003) and importance-performance analysis (IPA) maps (Martilla, James 1977; Wu, Shieh 2009).

The main objectives of the proposed framework are: (1) to assist executives at construction firms in identifying basic knowledge management practices; (2) to pro- 
vide a foundation on which systems and processes intended to create effective knowledge management practices can be built, and (3) to provide executives of construction firms with an internal reporting tool to use to evaluate and benchmark their firm's knowledge management practices.

\section{Benchmarking}

Benchmarking is one of the most powerful performance modeling approaches. It provides a systematic framework for identifying, classifying, and evaluating firms' processes, activities and performances. The primary objective of benchmarking is continuous improvement through observing the activities of other firms (Camp 1989). Different types of benchmarking have been proposed in the literature. Spendolini (1992) classifies benchmarking into three major types: (1) internal; (2) competitive; (3) generic. Internal benchmarking involves a firm's efforts to explore and analyze best practices within its departments and functions and to transplant uncovered best practices to other departments and functions. Competitive benchmarking involves a firm's efforts to analyze the best practices of its rivals and to imitate discovered best practices in its operations and activities. Generic benchmarking refers to a firm's efforts to explore the best practices of firms other than its rivals that are operating in the same industry or even firms operating in other industries. Competitive benchmarking has been one of the most commonly used benchmarking types in the literature. Competitive benchmarking is commonly carried out by completing a number of tasks. The basic tasks of competitive benchmarking include the following: (1) identifying what is to be benchmarked; (2) developing a benchmarking model; (3) selecting rival firm(s) to be used in benchmarking (i.e., comparative firms); (4) collecting data for benchmarking; (5) analyzing data for benchmarking; (6) presenting conclusions and recommendations regarding practices that need improvement (e.g., Camp 1989). The following section addresses the first task of competitive benchmarking. It presents a succinct review of the knowledge management literature.

\section{Knowledge management}

The concept of knowledge management has been at centre stage in the management literature for more than a decade. Knowledge management refers to the creation and subsequent management of an environment that encourages knowledge to be created, shared, learned and organized for the benefit of the firm (Sarrafzadeh et al. 2006). The earliest research studies on knowledge management have been predominantly driven by technical perspective (i.e., information systems - IS). Technical perspective primarily focuses on technical aspects (i.e., processes, tasks, and technology) of knowledge management. Subsequent recent research studies have shifted their focus from technical aspects of knowledge management to social aspects (i.e., relationships among people, attributes of people, reward systems, and authority structures) of knowledge management. The contemporary research studies on knowledge management (e.g., Lee, Choi 2003; Chuang 2004) build on the social-technical perspective (i.e., a synthesis of the social and technical perspectives). The central goal of these research studies has been to identify the primary knowledge management practices, and those that have emerged include: (1) knowledge management processes and (2) knowledge management enablers. The term knowledge management processes refers to the acquisition (i.e., capturing knowledge), conversion (i.e., making captured knowledge available), application (i.e., degree to which knowledge is useful), and protection (i.e., security of the knowledge) of knowledge (Gold et al. 2001). The knowledge acquisition process involves searching for and finding entirely new knowledge or creating new knowledge out of existing knowledge through collaboration. The knowledge application process involves the utilization of knowledge to improve the efficiency and effectiveness of activities and operations. The knowledge conversion process involves the transfer of knowledge among social actors (i.e., groups and individuals). The knowledge protection process involves securing knowledge from inappropriate and illegal use or theft.

The term knowledge management enablers refers to the organizational mechanisms that stimulate creating and developing knowledge within an organization and also facilitate its sharing, diffusion and protection (Lee, Choi 2003; Yeh et al. 2006). They provide a foundation on which effective knowledge management can be built. Chuang (2004) decomposes knowledge management enablers into two groups: (1) technical knowledge management enablers and (2) social knowledge management enablers. Technical knowledge enablers include a number of information and communication technologies (ICT) such as data processing, storage, communication, and management information systems used by the firm to support and enhance the creation, storage/retrieval, transfer, application, and sharing of organizational knowledge. Information and communication technologies constitute the technical infrastructure that enables firms to (1) facilitate the rapid collection, storage, and exchange of knowledge; (2) integrate fragmented flows of knowledge; (3) create new knowledge. Information and communication technologies create an interconnected environment that integrates and enhances the volume of knowledge flows originating from different phases of the construction process, department/units and locations. This interconnected environment enables a construction firm to (1) improve collaboration and teamwork; (2) intensify and expand interactions among its social actors (i.e., employees and departments/units); (3) overcome time and geographic location constraints in communication and coordination; (4) improve the creation, search for, accumulation and diffusion of organizational knowledge; (5) facilitate the storage, arrangement and sharing of organizational knowledge; (6) increase transmission and response speed in business and construction operations by organizing organizational knowledge and making it available whenever and wherever it is needed in the firm (Tseng 2008). 
The term social knowledge management enablers refers to the sum of the actual and potential resources available that derive from the relationships and interactions of social actors (i.e., individual, department and firm) (Nahapiet, Ghoshal 1998). Some scholars (e.g., Gold et al. 2001; Chuang 2004) view social knowledge management enablers as the social infrastructure that positively influences knowledge management effectiveness and decompose it into two components: (1) organizational culture and (2) organizational structure. Organizational culture includes a set of values, norms, beliefs, expectations, and assumptions that is widely shared in an organization (Huber 2001). Drucker et al. (1996) consider organizational culture as the "corporate glue" that binds social actors to the goals and objectives of the organization. This corporate glue informally shapes the values, assumptions, beliefs, and behaviors of the social actors that can encourage or impede the creation, sharing and diffusion of organizational knowledge. Previous research studies (e.g., Chen, Huang 2007; Nayir, Uzunçarsili 2008) have suggested that openness, mutual trust, and collaboration are the three essential components of organizational culture that influence knowledge management activities. A sense of openness in an organization enhances social interactions among social actors and in turn motivates social actors to share their ideas, insights, and knowledge. It eliminates barriers to effective knowledge exchange and even facilitates substantial and influential knowledge exchange among employees. A sense of strong mutual trust increases the commitment of social actors to common goals and reduces their fears. Finally, a sense of strong collaboration creates an environment wherein social actors willingly cooperate with each other instead of simply working together because they are forced to do so. Such an environment encourages social actors to discuss their work with other colleagues and to ask others for assistance when needed, and it leads to high levels of participation in the processes of capturing and transferring knowledge.

Organizational structure can be considered a social architecture of roles and flows of authority, work materials, information, and decision-making processes that make up an organization (Pennings 1992). It provides a social framework for the transformation of inputs (i.e., human, capital, physical and knowledge resources) into outputs (i.e., contracting services, constructed facility). This social framework formally shapes the behaviors of social actors and acts as an information and knowledge filter that can limit what a social actor sees in its operating environment (Claver-Cortés et al. 2007), and influence how a social actor perceives and interprets its environment. Therefore, organizational structure can facilitate or inhibit knowledge management behaviors and in turn knowledge management performance. Some researchers (Chuang 2004; Claver-Cortés et al. 2007) argue that competing in today's business environment requires an organizational structure that: (1) encourages sharing and collaboration with regard to knowledge across boundaries; (2) motivates and rewards employees to create and share their knowledge; (3) facilitates the creation and the discovery of new knowledge; (4) promotes collective rather than individualist behavior, and (5) enables knowledge exchange between social actors to solve new problems, and facilitates creation, utilizing diffusion and sharing organizational knowledge.

\section{Knowledge management and AEC firms}

Knowledge management has emerged as a key organizational capability that provides a systematic framework that AEC firms can use to foster, develop, and capitalize on its most valuable resource, which is knowledge. The main driving force behind the emergence of knowledge management as a key organizational capability for AEC firms can be better explained by reviewing the industry context in which AEC firms operate. This context is characterized as project-based, knowledge-intensive, demand-driven, and fragmented. Each project is a unique solution to a specific design problem (Zavadskas et al. 2010) reflecting the needs of a client. AEC firms develop abstract solutions to design problems and then transform the solutions into physical reality. This process is a knowledge-intensive process that requires the generation and processing of enormous volumes of information and knowledge. For the most part, the knowledge requirements for a construction project are dynamic processes that change from one project to another. The changes are necessary because each project requires its own design and generates new production problems regarding the integration and coordination of the outputs of specialized groups that conduct interdependent tasks. The demand for the AEC industry's products/services commonly takes the form of pre-demand purchase (i.e., before the construction project has begun). The client of the AEC industry commonly initiates the construction project, which is then conducted by a temporary alliance of autonomous and heterogeneous organizations called Temporary MultiOrganizations (TMOs). Each independent member of a TMO (i.e., architects, engineers, construction material vendors, general contractors, and sub-contractors) conducts interdependent and specialized tasks for achieving the objectives of the project. The process of meeting the needs and requirements of the client is composed of a series of interdependent sub-processes (i.e., different phases of a project). Autonomous and heterogeneous AEC firms are involved in each sub-process. The presence of a series of interdependent sub-processes (e.g., conception, design, and construction) leads to vertical fragmentation, whereas the involvement of autonomous and heterogeneous AEC firms to conduct interdependent tasks in each sub-process causes horizontal fragmentation (i.e., different specialists involved in a project). Both horizontal fragmentation and vertical fragmentation commonly act as a barrier for sharing and distributing knowledge among autonomous and heterogeneous members of the TMO. Ensuring efficient and effective flow of knowledge among members of the TMO is the key factor for achieving the objectives of project. Furthermore, AEC firms that are involved in TMOs rely extensively on knowledge accumulated from previous projects, but, 
eventually, a TMO disbands when the project is completed without sharing, discussing, or disseminating valuable knowledge that was accumulated during the project (Carrillo, Anumba 2002). As a result, such valuable knowledge is commonly lost. Capturing accumulated knowledge from previous projects is essential if AEC firms expect to meet the needs of their clients in future projects.

There is overwhelming anecdotal and empirical evidence (e.g., Chuang 2004; Claver-Cortés et al. 2007) that knowledge management practices present significant potential benefits to construction firms. These potential benefits can be at the project level and firm level. Projectlevel benefits include: (1) introducing innovative construction methods and contracting services; (2) improving coordination and communication among project participants; (3) reducing the cost of operations and processes; (4) improving timelines for construction operations and processes; (5) enhancing the quality of contracting services and constructed facilities; (6) sharing best practices, lessons learned, techniques and processes for construction operations and their management; (7) increasing client satisfaction. On the other hand, the firm-level benefits of knowledge management practices include: (1) improving overall firm performance; (2) creating and sustaining competitive advantage; (3) identifying opportunities for new construction projects and markets; (4) developing consciousness within the firm about the idea that knowledge assets do matter. A construction firm's ability to capture these potential benefits of knowledge management practices depends upon the effectiveness of its knowledge management practices. Therefore, it is essential for construction firms to evaluate and benchmark their knowledge management practices by developing or adopting a benchmarking model.

\section{Model development}

The knowledge management benchmarking model proposed in this paper builds on the concepts that have been set forth by knowledge management (e.g., Gold et al. 2001; Lee, Choi 2003) and on importance-performance analysis maps (Martilla, James 1977). It involves a fourstep procedure for benchmarking the knowledge management practices of construction firms. These steps are as follows: Step 1. Identifying evaluation criteria for the knowledge management practices of construction firms; Step 2. Rating the knowledge management practices of construction firms; Step 3. Determining the importance weights of knowledge management practices; Step 4. Constructing a confidence interval-based importance-performance analysis (CI-IPA) map for the benchmarked firm(s).

Step 1. Selecting knowledge management practices for benchmarking

The first step in evaluating the knowledge management practices of construction firms is selecting the knowledge management practices $\left(C_{i}\right)(I=1,2, \ldots h)$ that will be used during the benchmarking process. Different knowledge management models (e.g., Gold et al. 2001; Lee, Choi 2003) have been set forth in literature. The preceding section reveals that the most important knowledge management practices $\left(C_{i}\right)$ that influence a firm's knowledge management performance include organizational culture $\left(C_{1}\right)$, organizational structure $\left(C_{2}\right)$, information and communication technology $\left(C_{3}\right)$, knowledge acquisition $\left(C_{4}\right)$, knowledge conversion $\left(C_{5}\right)$, knowledge application $\left(C_{6}\right)$, and knowledge protection $\left(C_{7}\right)$ (see Table 1).

Table 1. Knowledge management practices $\left(C_{i}\right)$

\begin{tabular}{cc}
\hline Criteria $\left(C_{i}\right)$ & Description \\
\hline$C_{1}$ & Organizational Culture \\
$C_{2}$ & Organizational Structure \\
$C_{3}$ & Information and Communication Technology \\
$C_{4}$ & Knowledge Acquisition \\
$C_{5}$ & Knowledge Conversion \\
$C_{6}$ & Knowledge Application \\
$C_{7}$ & Knowledge Protection \\
\hline
\end{tabular}

Step 2. Rating Knowledge Management Practices of Construction Firms

The second step is rating the knowledge management practices $\left(C_{i}\right)$ of construction firms. A construction firm's knowledge management practices can be evaluated using a two-stage process: (1) developing a set of multiitem scales for measuring each knowledge management practice $\left(C_{i}\right)$ and then (2) rating the construction firm's level of achievement with regard to each item using $\mathrm{Li}$ kert-type scales. Using multi-item scales to measure each knowledge management practice enhances the reliability of the rating process. The questionnaire survey method can be used to collect data on construction firms' performance ratings for knowledge management practices.

The performance rating of $i$ th knowledge management practice $\left(R_{i, q}\right)$ for construction firm $q(q=1,2, \ldots N)$ can be derived from the following formula:

$$
R_{i, q}=\frac{1}{k} \sum_{j=1}^{k} r_{j},
$$

where $r_{j}(j=1,2, \ldots k)$ is the achievement level for the $j$ th item measuring the performance of the knowledge management practice $R_{i, q}, k$ is the number of items used to measure the performance of $i$ th knowledge management practice, and $N$ is number of construction firms participated in survey.

\section{Step 3. Deriving the importance weights of knowledge management practices}

The third step involves identifying the importance weight of each knowledge management practice $\left(W_{i}\right)$. The most common approach used in determining the importance of a criterion is the use of linguistic variables (e.g., low importance, moderate importance, very strong importance) (e.g., Kale 2009; Plebankiewicz 2009). The importance weight of $i$ th knowledge management practice $\left(W_{i}\right)$ can be derived using the following formula:

$$
W_{i}=\frac{1}{N} \sum_{q=1}^{N} w_{i, q},
$$


where $w_{i, q}$ is the importance weight assigned to $i$ th knowledge management practice by an evaluator from construction firm $q(q=1,2, \ldots N)$.

\section{Step 4. Constructing the Confidence Interval-Based Importance-Performance Analysis (CI-IPA) Map}

The fourth step in evaluating knowledge management practices is creating the Confidence Interval-Based Importance-Performance Analysis (CI-IPA) map for the case firm (i.e., the firm to be benchmarked) (Fig. 1) Confidence Interval-Based Importance-Performance Analysis is an extension of the Importance-Performance Analysis (IPA) map originally proposed by Martilla and James (1977). It incorporates the concept of confidence intervals and competitive dynamics into the IPA map (e.g., Dolinsky 1991; Wu, Shieh 2009). Constructing the CI-IPA map involves a two-stage process. The first stage involves: (1) computing the mean performance ratings of construction firms $(\bar{R})$ (i.e., industry average performance ratings) and the mean importance weights of knowledge management practices $(\bar{W})$ (i.e., the grand mean of importance weights); (2) selecting the confidence level $(1-\alpha)$; (3) computing the lower $\left[\mathrm{UB}_{(1-\alpha)}\right]$ and upper $\left[\mathrm{LB}_{(1-\alpha)}\right]$ bounds of confidence interval $\left[\left(\mathrm{CI}_{(1-\alpha)}\right]\right.$ of the mean performance ratings of the construction firms $(\bar{R})$ for the selected confidence level $(1-\alpha)$. Mean importance weights (i.e., grand mean) of knowledge management practices can be computed using the following formula:

$$
\bar{W}=\frac{1}{h} \sum_{i=1}^{h} W_{i},
$$

where $h$ is the number of criteria used in performance evaluation.

Mean performance ratings (i.e., industry average or grand mean) for knowledge management practices at the construction firms that participated in the evaluation process can be computed by using Eq. (4):

$$
\begin{gathered}
\bar{R}=\frac{1}{h} \sum_{i=1}^{h} R_{i}, \\
R_{i}=\frac{1}{N} \sum_{q=1}^{N} R_{i, q},
\end{gathered}
$$

where $R_{i}$ represents the mean performance rating of $i$ th knowledge management practice.

The confidence interval $(C I)$ of the mean performance rating for a desired confidence level $(1-\alpha)$ can be defined as follows:

$$
\begin{gathered}
C I_{(1-\alpha), \bar{R}}=\bar{R} \pm Z_{\alpha / 2} \frac{\bar{S}}{\sqrt{N}}, \\
\bar{S}=\frac{1}{h} \sum_{i=1}^{h} \sigma_{i},
\end{gathered}
$$

where $\bar{S}$ is the pooled sample standard deviation estimate of the performance rating, $\sigma_{i}$ is the standard deviation of the performance rating of the $i$ th knowledge management practice, and $Z$ is the tabulated value at $\alpha / 2$. The tabulated $Z$ value can be found in statistics books. The second stage of constructing a CI-IPA map is to select the construction firm to be benchmarked (i.e., case firm). The CI-IPA map provides important insights for prioritizing and developing action plans for improving the knowledge management practices of the case firm (Fig. 1). The horizontal and vertical axes of the CI-IPA map are the importance weight of knowledge management practices and the performance ratings of the case firm (i.e., $q$ th construction firm), respectively. The horizontal axis of the CI-IPA map (i.e., x-axis) was divided into three areas by drawing two perpendicular lines. The first perpendicular line represents the lower bound of the selected confidence interval of the mean of the performance ratings $\left(L B_{(1-\alpha), \bar{R}}\right)$. The second perpendicular line represents the upper bound of the confidence interval of the mean of the performance ratings $\left(U B_{(1-\alpha), \bar{R}}\right)$ for the selected confidence level $(1-\alpha)$. The vertical axis of the CI-IPA map (i.e., the y-axis) was divided into two areas by drawing a perpendicular line representing the grand mean of importance weights of knowledge management practices $(\bar{W})$.

The CI-IPA map consists of six cells (Fig. 1). Each of the cells is a combination of importance weights $\left(W_{i}\right)$ and performance ratings for knowledge management practices $\left(R_{i}\right)$. The labeling of the cells is based on Dolinsky's (1991) study, which intuitively incorporates the competitive dynamic into conventional importance and performance analysis (IPA) map.

Cell I-Competitive disadvantage zone. This represents the knowledge management practices that are the construction firm's major weakness(es). Each knowledge management practice located in this zone needs immediate corrective action because it has relatively high importance but the case firm performs lower than the industry average. Therefore, the construction firm should focus on improving each knowledge management practice located in this zone.

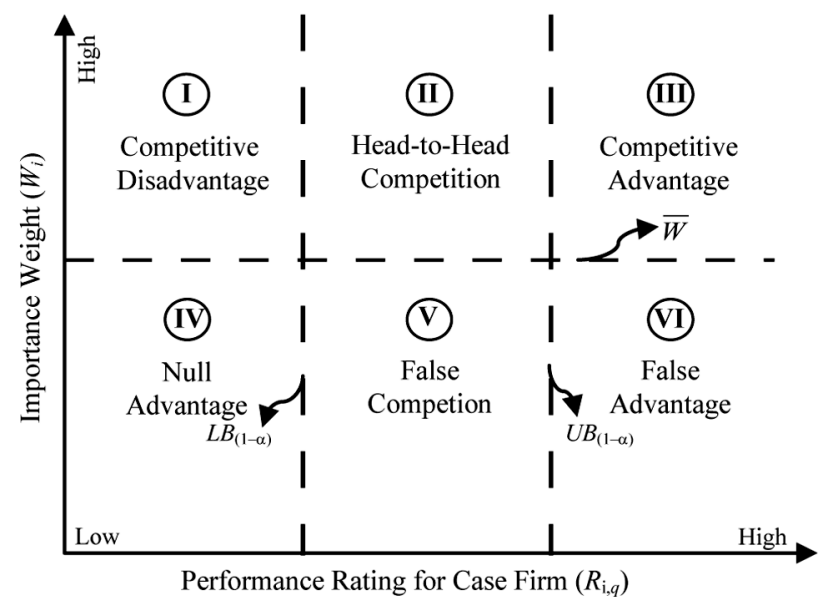

Fig. 1. Confidence interval based importance - performance analysis (CIPA) map 
Cell II - Head-to-head competition zone. This zone points to knowledge management practice(s) for which the case firm performs very close to the industry average. The case firm does not have a distinct advantage over its rivals with regard to the knowledge management practice(s) located in this zone. The case firm is facing intense competition with regard to this knowledge management practice. However, each knowledge management practice located in this zone is of moderate importance. Therefore, the case firm should closely monitor knowledge management practices located in this zone.

Cell III - Competitive advantage zone. This zone includes knowledge management practice(s) that are of high importance and where the case firm performs higher than the industry average. Therefore, each of the knowledge management practices located in this zone can be considered a major strength for the case firm. Cell III indicates knowledge management practices that can be a source of competitive advantage for the case firm. Therefore, the construction firm should maintain its position on each knowledge management practice located in this zone.

Cell IV-Null advantage zone. This zone features knowledge management practices that have relatively low importance and where the case firm performs lower than the industry average.

Cell $V$-False competition zone. This zone includes knowledge management practices that need no immediate action. Each of the knowledge management practices located in this zone should be closely monitored because a change in the relative importance of this knowledge management practice could turn it into a major weakness and in turn a competitive disadvantage for the case firm.

Cell VI-False advantage zone. This zone includes knowledge management practices that the case firm performs better than its rivals but for which high performance does not imply competitive advantage for the case firm over its rivals because the knowledge practice located in this zone is of relatively low importance. Therefore, the case firm should consider re-organizing or restructuring the knowledge management practice located in this zone and directing its efforts and resources to the other knowledge management practices that need improvement.

\section{Model application}

The application of the performance evaluation model proposed in the preceding section was carried out in three phases: (1) collecting data on the performance ratings of knowledge management practices $\left(R_{i}\right)$ and importance weights of knowledge management practices $\left(W_{i}\right)$ of construction firms; (2) selecting a construction firm to be benchmarked (i.e., the case firm), and (3) creating a CI-IPA map for the knowledge management practices of the selected construction firm (i.e., the case firm).

\section{Sample and Data Collection}

Previous research studies have suggested that firm size can have overarching implications on knowledge management activities (e.g., Chen, Mohammed 2007) and that the number of employees can be used as a proxy for measuring the size of AEC firms (e.g., Kale, Arditi 2003). In light of these suggestions, a sample of 300 construction firms that have more than 20 employees was constructed using directories and online databases to illustrate the application of the proposed model. Different formal and informal communication channels were used to reach these construction firms and request their participation in the survey. The final sample size $(N)$ used in the benchmarking decreased from 300 to 105 construction firms because some of the construction firms could not be contacted, some others declined to participate, and still others agreed to participate but failed to provide the requested information in a timely or complete manner. The effective rate of return for the survey was $35 \%$. This rate of return compares well with previous research studies of knowledge management in AEC firms (e.g., Y. C. Lin, L. K. Lin 2006; Chen, Mohammed 2007). Table 2 presents demographic information for the participating firms. The key informants who participated in the application of the proposed model were top executives at construction firms such as presidents, vice presidents or chief executive officers. These individuals were considered to be the most knowledgeable persons regarding their firm's knowledge management practice ratings and the importance of each knowledge management practice.

Table 2. Demographic profile of participating construction firms

\begin{tabular}{ccc}
\hline Firm Size & Number of Firms & Percentage \\
\hline $20-40$ & 35 & $33 \%$ \\
$41-60$ & 7 & $7 \%$ \\
$61-100$ & 11 & $10 \%$ \\
$101-200$ & 15 & $14 \%$ \\
$201-500$ & 20 & $19 \%$ \\
Over 500 & 17 & $16 \%$ \\
\hline Firm Age & & \\
$1-10$ & 18 & $17 \%$ \\
$11-20$ & 22 & $21 \%$ \\
$21-30$ & 26 & $25 \%$ \\
$31-40$ & 17 & $16 \%$ \\
$41-50$ & 15 & $14 \%$ \\
Over 50 & 7 & $7 \%$ \\
\hline
\end{tabular}

A questionnaire entitled Knowledge Management Benchmarking Instrument (KMB-I) was prepared based on a succinct review of previous research studies on knowledge management (e.g., Gold et al. 2001; Lee, Choi 2003). KMB-I consists of three parts. The first part of the KMB-I includes a series of open-ended questions that solicit demographic information on the surveyed construction firms. The second part of KMB-I includes a set of items for evaluating construction firms' knowledge management practices $\left(R_{i}\right)$. On the second part of the evaluation form, the respondents were instructed to rate the extent to which they agreed with each item on a seven-point Likert type scale that ranged from " 1 = strongly disagree" to "7 = strongly agree". Items used for measuring knowledge management practices $\left(R_{i}\right)$ were taken from Gold et al. (2001) study. The wording of the items was slightly modified to adapt them to the construction 
Table 3. Cronbach Alpha values, importance weights and performance ratings

\begin{tabular}{cccccc}
\hline $\begin{array}{c}\text { Criteria } \\
\left(C_{i}\right)\end{array}$ & $\begin{array}{c}\text { Cronbach Alpha } \\
\text { for }\left(R_{i}\right)\end{array}$ & $\begin{array}{c}\text { Importance Weight } \\
\left(W_{i}\right)\end{array}$ & \multicolumn{2}{c}{ Industry Performance Rating } & $\begin{array}{c}\text { Case Firm Perfor- } \\
\text { mance Rating }\left(R_{i, q}\right)\end{array}$ \\
\hline$C_{1}$ & 0.84 & 5.74 & Mean $\left(R_{i}\right)$ & Std.Dev. $\left(\sigma_{i}\right)$ & 5.80 \\
$C_{2}$ & 0.84 & 5.27 & 5.71 & 0.80 & 5.64 \\
$C_{3}$ & 0.83 & 5.62 & 4.94 & 0.73 & 5.27 \\
$C_{4}$ & 0.87 & 5.69 & 5.70 & 0.83 & 5.86 \\
$C_{5}$ & 0.93 & 5.62 & 5.37 & 0.97 & 5.22 \\
$C_{6}$ & 0.93 & 5.75 & 5.60 & 0.90 & 5.33 \\
$C_{7}$ & 0.89 & 5.51 & $\bar{R}=\mathbf{5 . 3 8}$ & $\bar{S}=\mathbf{0 . 9 2}$ & 4.88 \\
\hline Average & - & $\bar{W}=\mathbf{5 . 6 0}$ & $\bar{R}$ & - \\
\hline
\end{tabular}

industry context. The third part of KMB-I includes a series of questions measuring the importance of each knowledge management practice $\left(W_{i}\right)$ on a Likert-type scale ranging from " 1 = very low importance" to "7 = very high importance".

\section{Methods}

The reliability of the multi-item scales used to measure the performance ratings for knowledge management practices (i.e. $R_{i}$ ) is assessed by using the Cronbach's alpha method. The Cronbach's alpha values of the performance ratings are above the recommended threshold level of 0.70 (e.g., Nunnally 1978) (Table 3). They range from a low of 0.83 to a high of 0.93 . Therefore, it is concluded that the multi-item scales used to measure the knowledge management practices $\left(R_{i}\right)$ are reliable. The means $\left(R_{i}\right)$ and standard deviations $\left(\sigma_{i}\right)$ of performance ratings of knowledge management practices are presented in Table 3 . The mean performance ratings for the knowledge management practices $\left(R_{i}\right)$ of the surveyed construction firms range from a high of 5.79 to a low of 4.54. The grand mean performance rating for the knowledge management practices of the surveyed construction firms $(\bar{R})$ is 5.38 . Table 3 also presents the mean importance weights of the knowledge management practices $\left(W_{i}\right)$ and their grand mean $(\bar{W})$. The survey results indicate that the most important knowledge management practice for construction firms is their knowledge application process $\left(W_{6}=5.75\right)$, whereas the least important knowledge management practice for construction firms is their knowledge protection process $\left(W_{7}=5.51\right)$. The grand mean importance weight $(\bar{W})$ of knowledge management practices is 5.60.

Constructing a CI-IPA map requires selecting the confidence level $[(1-\alpha) \%]$ for a confidence interval [CI $(1-\alpha)]$ of the mean performance ratings. The most commonly used confidence level in research studies and in practice is $95 \%$. Therefore, the chosen confidence level for constructing confidence CI-IPA map for the case firm was $95 \%$. For a $95 \%$ confidence level, $\alpha$ is 0.05 and the tabled $Z$ value at $0.5 / 2(0.025)$ is 1.96 . The $95 \%$ confidence interval $\left[\mathrm{CI}{ }_{(0.95)}\right]$ of the mean performance ratings was computed using Eq. 6. The lower $\left(L B_{0,95, \bar{R}}\right)$ and upper bounds $\left(U B_{0.95, \bar{R}}\right)$ of the confidence interval at a $95 \%$ confidence level are 5.20 and 5.55, respectively.
A construction firm was selected as the case firm (i.e. the firm to be benchmarked) in this study to illustrate the use of the proposed model, which is a common research approach that has been used in previous performance measurement modeling studies in the construction management domain (e.g., Kale 2009; Tupenaite et al. 2010). The case firm is based in Istanbul, Turkey. It has more than 200 full-time employees. Its turnover was over $\$ 225$ million in 2010. It generally undertakes infrastructure and general building projects. The performance ratings of the case firm $\left(R_{i, q}\right)$ are presented in Table 3. The case firm's organization culture has the highest performance rating $\left(R_{1, q}=5.80\right)$, whereas its knowledge acquisition process has the lowest performance rating $\left(R_{4, q}=\right.$ 4.86).

The CI-IPA map for the case firm (i.e., construction firm $q$ ) is presented in Fig. 2. A visual inspection of the CI-IPA map of the case firm indicates several important issues. First, the knowledge acquisition process $\left(C_{4, q}\right)$ of the case firm is located in the competitive disadvantage zone (i.e., Cell I). The case firm's performance rating for the knowledge acquisition process $\left(R_{4, q}=4.86\right)$ is well below the industry average performance rating $\left(R_{4}=\right.$ 5.70). However, the knowledge acquisition process has the third highest importance weight $\left(W_{4}=5.69\right)$. It is the highest priority for immediate managerial action. Therefore, the case firm should immediately develop a managerial action plan for improving its knowledge acquisition process.

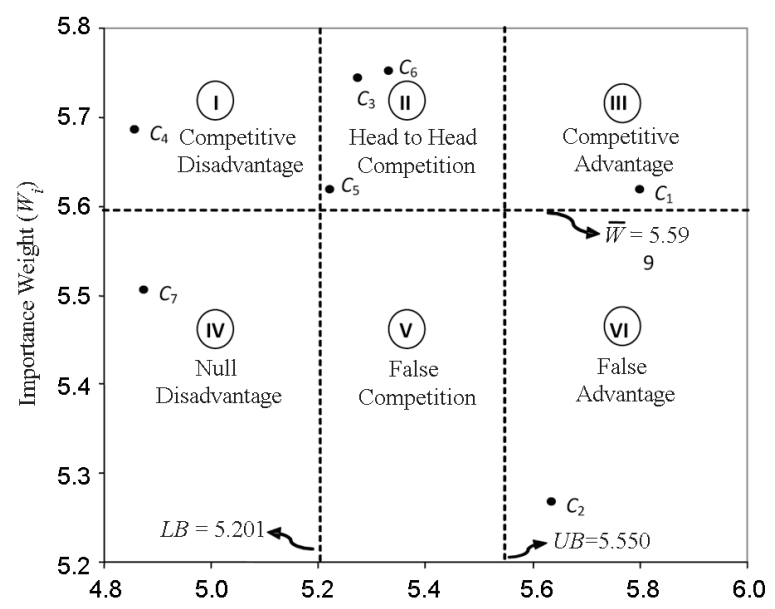

Fig. 2. Case study - CIPA map 
Second, information and communication technology $\left(C_{3, q}\right)$, the knowledge conversion process $\left(C_{5, q}\right)$ and the knowledge application $\left(C_{6, q}\right)$ of the case firm are located in the head-to-head competition zone (i.e., Cell II). The case firm should adopt a dual focus approach for knowledge management practices located in this zone. A dual focus approach implies improving the performance ratings of knowledge management practices located in the head-to-head competition zone (Cell II) to move them to the competitive advantage zone (Cell III) while closely monitoring their importance weights and performance ratings. Therefore, the case firm should seek the means to increase its performance ratings for information and communication technology $\left(C_{3, q}\right)$, the knowledge conversion process $\left(C_{5, q}\right)$, and the knowledge application $\left(C_{6, q}\right)$ to turn them into sources of competitive advantage. The highest priorities for managerial actions should be the knowledge application process $\left(C_{6, q}\right)$ and information and communication technology $\left(C_{3, q}\right)$ because they have the second and third highest importance weights, respectively. The case firm should closely monitor its performance rating for the knowledge conversion process $\left(C_{5, q}\right)$ because its performance rating for this knowledge management practice is marginally higher than the lower bound $\left(L B_{0.95, \bar{R}}=5.20\right)$ of the $95 \%$ confidence interval of mean of the performance ratings. Therefore, a slight decrease in performance rating could move this competence into the competitive disadvantage zone (i.e., Cell I). The case firm should also closely monitor the knowledge conversion process because its importance weight $\left(W_{5}=5.62\right)$ is slightly bigger than the grand mean importance weight $(\bar{W}=5.60)$. A slight increase in the grand mean importance weight can move the knowledge conversion process to the false competition zone (Cell V). Therefore, the case firm should closely monitor its knowledge conversion process. Third, the organizational culture $\left(C_{1, q}\right)$ of the case firm is located in the competitive advantage zone (Cell III). It is a major strength of the case firm $\left(R_{1, q}=5.80\right)$. It appears that the organizational culture of the case firm creates a supportive environment for its employees to use to engage in knowledge management activities. Therefore, the case firm should maintain its good performance in the area of this knowledge management practice. Fourth, the knowledge protection process $\left(C_{7, q}\right)$ of the case firm is located in the null advantage zone (Cell IV). The case firm performs poorly with regard to this knowledge management practice. However, the knowledge protection process exhibits the second lowest degree of importance $\left(W_{7}=5.51\right)$. Therefore, it is a relatively low priority for managerial action. Fifth, the organization structure $\left(C_{2, q}\right)$ of the case firm is located in the false advantage zone (i.e., Cell VI). The case firm's performance rating for this knowledge management practice $\left(R_{2, q}=5.64\right)$ is marginally higher than the upper bound $\left(U B_{0.95, \bar{R}}=5.55\right)$ of the $95 \%$ confidence interval of the mean performance ratings. However, organization structure has the lowest relative importance $\left(W_{2}=5.27\right)$. Therefore, it presents a false advantage for the case firm.
The results of the proposed model were presented to the executives of the case firm. The feedback received from the executives of the firm provided some support for the utility and validity of the proposed model. In the light of the diagnostic information provided by the proposed model, the case firm is considering to initiate a managerial action plan for improving its knowledge acquisition process.

\section{Conclusions and implications}

There is increasing recognition that knowledge management is a key organizational capability for AEC firms in today's business environment. Therefore, AEC firms should develop or adopt models, tools, and techniques that can enable them to benchmark and improve their knowledge management practices. The research presented here proposes a benchmarking model to address these issues. It builds on concepts set forth by benchmarking and knowledge management models and importanceperformance analysis maps.

The model proposed in this paper is a simple visual tool that can be easily used by construction business executives but is capable of presenting powerful diagnostic information on AEC firms' knowledge management practices. It has several practical implications for AEC firms. First, the proposed model can be used by AEC firms as an internal performance measurement tool for evaluating knowledge management practices. Second, it derives the importance weights of knowledge management practices by surveying a sample of construction firms. Importance weights for knowledge management practices can be used by construction firms to evaluate and benchmark their knowledge management practices. Third, the proposed model brings competitive dynamics into the realm of performance evaluation. Therefore, it can provide structural guidance to AEC firms in identifying knowledge management practices that can be sources of competitive advantage or disadvantage. Fourth, the proposed model can guide AEC firms in developing priorities for managerial action plans and interventions for knowledge management practices that need immediate improvement. Furthermore, the proposed model can assist construction business executives in pinpointing those areas that need improvement if they are to succeed in the future. Finally, the proposed model can be used by AEC firms to identify areas of wasted efforts and/or overinvestment keeping in mind that AEC firms, like other firms, have limited resources (i.e., financial, human, time, and knowledge) and that the effective and efficient use of resources is the key to outperforming rivals.

The CI-IPA map presented in this paper is based on the perceptions of Turkish construction business executives. AEC firms operating in the Turkish construction industry can measure their knowledge management practices by using computed importance weights and industry average performance ratings and construct their own CIIPA maps. It should be noted that AEC firms operating in other parts of the world can also benefit from using computed importance weights and industry average performance ratings for knowledge management practices in 
constructing their confidence interval-based importanceperformance analysis maps. However, values for importance weights and industry average performance ratings for knowledge management practices should be used with caution because they can vary from country to country.

\section{References}

Camp, R. 1989. Benchmarking: the search for industry best practices that leads to superior performance. ASQC Quality Press, Milwaukee, Wisconsin. 299 p.

Carrillo, P.; Anumba, C. 2002. Knowledge management in the AEC sector, Knowledge and Process Management 9(3): 149-161. http://dx.doi.org/10.1002/kpm.146

Carrillo, P.; Chinowsky, P. 2006. Exploiting knowledge management: the construction and engineering perspective, Journal of Management in Engineering ASCE 22(1): 2-10. http://dx.doi.org/10.1061/(ASCE)0742-597X(2006) 22:1(2)

Chen, C.-J.; Huang, J.-W. 2007. How organizational climate and structure affect knowledge management - The social interaction perspective, International Journal of Information Management 27(2): 104-118.

http://dx.doi.org/ 10.1016/j.ijinfomgt.2006.11.001

Chen, M.-Y.; Huang M.-J.; Cheng, Y.-C. 2009. Measuring knowledge management performance using a competitive perspective: an empirical study, Expert Systems with Applications 36(4): 8449-8459.

http://dx.doi.org/10.1016/ j.eswa.2008.10.067

Chen, L.; Mohammed, S. 2007. Empirical study of interactions between knowledge management activities, Engineering, Construction and Architectural Management 14(3): 242260. http://dx.doi.org/10.1108/09699980710744890

Chuang, S.-H. 2004. A resource-based perspective on knowledge management capability and competitive advantage: an empirical investigation, Expert Systems with Applications 27(3): 459-465.

http://dx.doi.org/10.1016/j. eswa.2004.05.008

Claver-Cortés, E.; Zaragoza-Sáez, P.; Pertusa-Ortega, E. 2007. Organizational structure features supporting knowledge management process, Journal of Knowledge Management 11(4): 45-47. http://dx.doi.org/10.1108/13673270710762701

Dolinsky, A. L. 1991. Considering the competition in strategy development: an extension of importance-performance analysis, Journal of Health Care Marketing 11(1): 31-36.

Drucker, J.; White, G.; Hegewisch, A.; Mayne, L. 1996. Between hard and soft HRM: human resource management in the construction industry, Construction Management and Economics 14(4): 405-416.

http://dx.doi.org/10.1080/014461996373278

Egbu, C. O. 2004. Managing knowledge and intellectual capital for improved organizational innovations in the construction industry: an examination of critical success factors, Engineering, Construction and Architectural Management 11(5): 301-315.

Fang, D. P.; Huang, X. Y.; Hinze, J. 2004. Benchmarking studies on construction safety management in China, Journal of Construction Engineering and Management ASCE 130(3): 424-432. http://dx.doi.org/10.1061/(ASCE)07339364(2004)130:3(424)

Gold, A. H.; Malhotra, A.; Segars, A. H. 2001. Knowledge management: an organizational capabilities perspective, Journal of Management Information Systems 18(1): 185214.
Huber, G. P. 2001. Transfer of knowledge in knowledge management systems: unexplored issues and suggested studies, European Journal of Information Systems 10(2): 7279. http://dx.doi.org/10.1057/palgrave.ejis.3000399

Kululanga, G. K.; McCaffer, R. 2001. Measuring knowledge management for construction organizations, Engineering Construction and Architectural Management 8(5-6): 346-354.

Kale, S. 2009. Fuzzy intellectual capital index for construction firms, Journal of Construction Engineering and Management ASCE 135(6): 508-517.

http://dx.doi.org/10.1061/(ASCE)CO.1943-7862.0000014

Kale, S.; Arditi, D. 2003. Differentiation, conformity, and construction firm performance, Journal of Management in Engineering ASCE 19(2): 52-59. http://dx.doi.org/ 10.1061/(ASCE)0742-597X(2003)19:2(52)

Lam, E. W. M.; Chan, A. P. C.; Chan, D. W. M. 2004. Benchmarking design-build procurement systems in construction, Benchmarking: An International Journal 11(3): 287-302.

Lee, H.; Choi, B. 2003. Knowledge management enablers, processes and organizational knowledge, Journal of Management Information Systems 20(1): 179-228.

Lin, Y. C.; Lin, L. K. 2006. Critical success factors for knowledge management studies in construction, in Proc. of The $23^{\text {rd }}$ "International Symposium on Automation and Robotics in Construction (ISARC 2006)", 3-5 October, 2006, Tokyo, Japan, 768-772.

Luu, V. T.; Kim, S.-Y.; Huynh, T.-A. 2008. Improving project management performance of large contractors using benchmarking approach, International Journal of Project Management 26(7): 758-769.

http://dx.doi.org/10.1016/j.ijproman.2007.10.002

Martilla, J. A.; James, J. C. 1977. Importance-performance analysis, Journal of Marketing 41(1): 77-79. http://dx.doi.org/10.2307/1250495

Nahapiet, J.; Ghoshal, S. 1998. Social capital, intellectual capital, and the organizational advantage, Academy of Management Review 23(2): 242-266.

Nayir, D. Z.; Uzunçarsili, U. 2008. A cultural perspective on knowledge management: the success story of Sarkuysan company, Journal of Knowledge Management 12(2): 141-155. http://dx.doi.org/10.1108/13673270810859578

Nunnally, J. C. 1978. Psychometric theory. $2^{\text {nd }}$ Ed. New York: McGraw-Hill College. 640 p.

Pathirage, C. P.; Amaratunga, D. G.; Haigh, R. P. 2007. Tacit knowledge and organizational performance: construction industry perspective, Journal of Knowledge Management 11(1): 115-126. http://dx.doi.org/10.1108/13673270710728277

Pennings, J. M. 1992. Structural contingency theory - A reappraisal, Research in Organizational Behavior 14: 267-309.

Plebankiewicz, E. 2009. Contractor prequalification model using fuzzy sets, Journal of Civil Engineering and Management 15(4): 377-385. http://dx.doi.org/10.3846/1392-3730.2009.15.377-385

Sarrafzadeh, M.; Martin, B.; Hazeri, A. 2006. LIS professionals and knowledge management: some recent perspectives, Library Management 27(9): 621-635. http://dx.doi.org/10.1108/01435120610715527

Sommerville, J.; Robertson, H. W. 2000. A scorecard approach to benchmarking for total quality construction, International Journal of Quality \& Reliability Management 17(4/5): 453-466. http://dx.doi.org/10.1108/02656710010298526 
Spendolini, M. J. 1992. The Benchmarking Book. New York: American Management Association. 209 p.

Tseng, S.-M. 2008. The effects of information technology on knowledge management systems, Expert Systems with Applications 35(1-2): 150-160.

http://dx.doi.org/10.1016/j.eswa.2007.06.011

Tupenaite, L.; Zavadskas, E. K.; Kaklauskas, A.; Turskis, Z.; Seniut, M. 2010. Multiple criteria assessment of alternatives for built and human environment renovation, Journal of Civil Engineering and Management 16(2): 257266. http://dx.doi.org/10.3846/jcem.2010.30

Wen, Y.-F. 2009. An effectiveness measurement model for knowledge management, Knowledge-Based Systems 22(5): 363-367.

http://dx.doi.org/10.1016/j.knosys.2009.02.007
Wu, H.-H.; Shieh, J.-I. 2009. The development of a confidence interval-based importance-performance analysis by considering variability in analyzing service quality, Expert Systems with Applications 36(3): 7040-7044. http://dx.doi.org/10.1016/j.eswa.2008.08.055

Yeh, Y.-J.; Lai, S.-Q.; Ho, C.-T. 2006. Knowledge management enablers: a case study, Industrial Management \& Data Systems 106(6): 793-810. http://dx.doi.org/10.1108/02635570610671489

Zavadskas, E. K.; Turskis, Z.; Tamošaitienè, J. 2010. Risk assessment of construction projects, Journal of Civil Engineering and Management 16(1): 33-46. http://dx.doi.org/10.3846/jcem.2010.03

Serdar KALE. Professor in the department of Architecture, Izmir Institute of Technology, Turkey. He received his PhD from the Department of Civil Engineering Illinois Institute of Technology, USA. His research interests include competitive advantage in the construction industry, intellectual capital, innovation diffusion.

A. Erkan KARAMAN. Assistant professor in the Department of Civil Engineering, Balikesir University, Turkey. He received his PhD from the Department of Civil Engineering, Balikesir University, Turkey. His research interests are in knowledge management and project scheduling. 